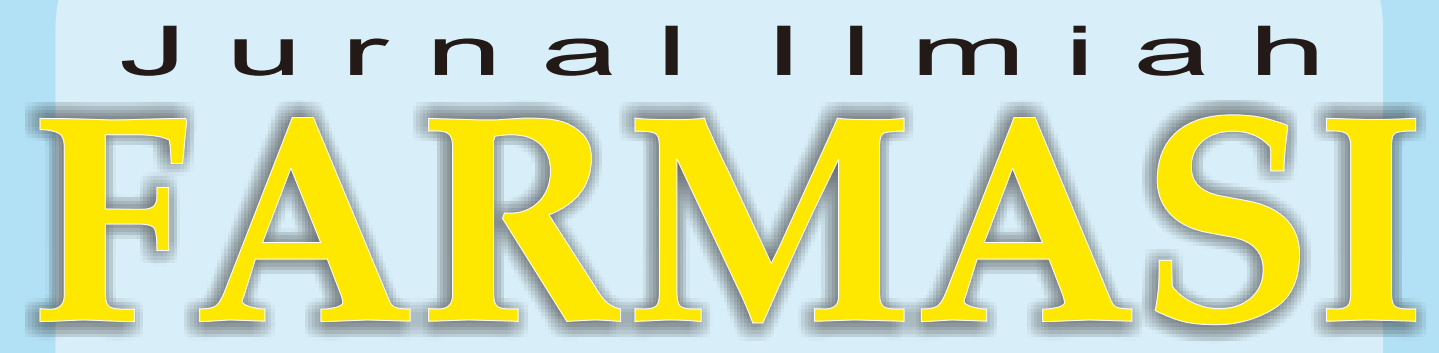

(Scientific Journal of Pharmacy) 
JURNAL ILMIAH FARMASI

(SCIENTIFIC JOURNAL OF PHARMACY)

PIMPINAN UMUM/ PENANGGUNG JAWAB

Dekan Fakultas Matematika dan Ilmu Pengetahuan Alam

Universitas Islam Indonesia

WAKIL PIMPINAN UMUM/ WAKIL PENANGGUNG JAWAB

Ketua Jurusan Farmasi FMIPA UII

\section{MITRA BESTARI}

1. Prof. Dr. Wiryatun Lestariana, Apt

2. Prof. Dr. Zullies Ikawati, Apt

3. Prof. Dr. Sudibyo Martono, Apt

4. Dr. Tedjo Yuwono, Apt

5. Prof. Dr. Dachriyanus, Apt

6. Prof. dr. Iwan Dwiprahasto, MMedSc, PhD

7. Prof. Dr. Lukman Hakim M.Sc., Apt

8. Prof. Dr. Achmad Fudholi, DEA, Apt

9. Prof. Dr. Ibnu Gholib Gandjar, DEA., Apt

\begin{tabular}{ll} 
& \multicolumn{1}{c}{ DEWAN EDITOR } \\
Ketua & : Saepudin, M.Si., Apt \\
Sekretaris & : Rochmy Istikharah, M.Sc., Apt. \\
Anggota & : Vitarani Dwi Ananda Ningrum, M.Si., Apt \\
& Okti R. Mafruhah, MSc., Apt \\
& Dimas Adhi Pradana, MSc., Apt. \\
& Fithria DA. Suryanegara, MSc., Apt. \\
& Ari Wibowo, S.Farm., Apt \\
& Arba Pramudita Ramadani, MSc., Apt. \\
& Oktavia Indrati, S.Farm., Apt.
\end{tabular}

Penerbit

Jurusan Farmasi Fakultas Matematika dan IImu Pengetahuan Alam Universitas Islam Indonesia

Alamat Penerbit Jurusan Farmasi FMIPA UII

Jl. Kaliurang Km. 14,4 Yogyakarta 55584

Telp. (0274) 896439 ext. 3047

Email: jif@uii.ac.id 


\title{
PENGHAMBATAN QUORUM SENSING SEBAGAI ALTERNATIF TERAPI PENYAKIT INFEKSI YANG DISEBABKAN OLEH BAKTERI
}

\author{
Shofyatul Yumna Triana, Farida Juliantina, Rachmawati
}

\begin{abstract}
The latest discoveries in the field of microbiology have proved that bacteria communicate each other. The process of cell to cell communication is called quorum sensing. Quorum sensing was first discovered in two luminous bacteria called Vibrio harveyi and Vibrio fischeri. These bacteria emit light in response to increase in cell population density. Density-dependent light production is accomplished trough the release and detection of hormone-like molecules called autoinducers that accumulate in the environment as the bacterial density increases. Quorum sensing is believed to regulate competence in development, sporulation, virulence factor induction, sporulation and nutrient flux along with other events in pathogenic bacterial infections. Recently, many scientist have been doing research in the field of quorum sensing. If the signaling systems among the bacteria were able to be blocked, the dangerous effects from bacteria then possibly be prevented. In other word, if the quorum sensing mechanism were stopped, the disease can be prevented or even cured instead of antibiotics use.
\end{abstract}

Keyword : bacterial infection - quorum sensing - inhibiton 